\title{
Experimental research on building material - ceramsite concrete
}

\author{
Jian qiang LI
}

School of civil engineering, University of Science and Technology Liaoning, Anshan 114000, China

Lijq992@163.com

Key words: ceramsite; anti-cracking ability; polypropylene fiber

Abstract:In order to study the strength and crack resistance of lightweight concrete, this paper made the concrete using lytag as coarse aggregate block, and join in the block of polypropylene fiber in order to improve its strength and crack resistance. Use control variable law for reference block, the following conclusions: through the experiment, when the standard test block ceramsite dosage is $1000 \mathrm{~g}$, dosage of fiber types $6 \mathrm{~mm}$ for $70 \mathrm{~g}$ can achieve optimal crack resistance and maximum compressive strength, and with continued increase in the amount of ceramsite concrete compressive strength of block is on the decline.

\section{Introduction}

Ceramsite concrete is a lightweight concrete material, which is mainly used for non load-bearing structural components. However, its strength is low, and its crack resistance is poor, which restricts its development and application, and can not completely replace ordinary concrete ${ }^{[1]}$. In order to improve its anti cracking performance and strength, in this paper, the author set the fly ash ceramsite as coarse aggregate, polypropylene fiber as special addition materials, to study the effect of dosages of ceramsite and fiber in a standard block for the concrete strength; at the same time to improve the degree of evaluation of fiber on crack resistance, and finally to find out the optimal mix ratio.

\section{Experiment}

\section{experimental materials}

(1) cement

The cement is a powdery water hard inorganic cementitious material. The specific surface area of P.O42.5 cement is $342 \mathrm{~m} 2 / \mathrm{kg}$, and the 28 day compressive strength is $45.3 \mathrm{MPa}$, which meets the standard requirements ${ }^{[2]}$.

(2) ceramsite

The particle size is $5 \mathrm{~mm}-15 \mathrm{~mm}$, the compressive strength of the cylinder is $1.3-3.5 \mathrm{MPa}$, the water absorption rate is less than $10 \%$, and the refractoriness is more than $500^{[3]}$.

(3) polypropylene fiber

Its main performance is shown in the table $1^{[3] \text {. }}$

Table 1: the main properties of polypropylene fiber

\begin{tabular}{lllllll}
\hline $\begin{array}{l}\text { Density } \\
\left(t / \mathrm{m}^{3}\right)\end{array}$ & $\begin{array}{l}\text { Modulus of } \\
\text { elasticity }\end{array}$ & $\begin{array}{l}\text { Tensile } \\
\text { strength } \\
(\mathrm{MPa})\end{array}$ & $\begin{array}{l}\text { Limit } \\
\text { expansion } \\
\text { rate }\end{array}$ & $\begin{array}{l}\text { Heat } \\
\text { resistance } \\
(\mathrm{MPa})\end{array}$ & $\begin{array}{l}\text { Melting } \\
\text { point }\end{array}$ & Colour \\
\hline $0.9-0.91$ & $(3 \sim 7) \times 10^{3}$ & $300 \sim 600$ & $18 \%$ & $121 \sim 160$ & $165 \sim 170$ & white \\
\hline
\end{tabular}


The dry mixing method is used to mix the aggregate and fiber to disperse the fibers so as to ensure good adhesion with mortar and improve adhesion. After mixing $2 \mathrm{~min}$, mix cement and water and continue stirring 2 3min.

(4) air entrained agent

The air entrained agent can greatly improve cement workability, pumping and improve durability such as anti seepage and frost resistance of concrete, it can effectively prevent the twice adsorption of commercial concrete and reduce the time loss of concrete slump ${ }^{[4]}$.

\section{Determination of the mixture ratio}

(1) calculation of the initial mix ratio

$$
f_{c u, 0}=f_{c u, k}+1.645 \sigma
$$

(2) Calculation of aggregate

In this experiment, the amount of cement is $500 \mathrm{~kg} / \mathrm{m}^{3}$ and the amount of water is $225 \mathrm{~kg} / \mathrm{m}^{3}$.

$$
\begin{gathered}
V_{\mathrm{s}}=\left[1-\left(\frac{m_{s}}{\rho_{c}}+\frac{m_{w n}}{\rho_{w}}\right)\right] \times S_{p} \\
\mathrm{~m}_{\mathrm{s}}=V_{s} \times \rho_{s} \\
V_{\mathrm{a}}=\left[1-\left(\frac{m_{c}}{\rho_{c}}+\frac{m_{w n}}{\rho_{w}}+\frac{m_{s}}{\rho_{s}}\right)\right] \\
\mathrm{m}_{a}=V_{a} \times \rho_{a p} \\
\rho_{\mathrm{cd}}=1.15 \mathrm{~m}_{\mathrm{c}}+\mathrm{m}_{\mathrm{a}}+\mathrm{m}_{\mathrm{s}}
\end{gathered}
$$

\section{(3) Determination of air entraining agent}

When the dosage of air entraining agent is generally at $0 \sim 0.5 \%$, the compressive strength and flexural strength of concrete are the highest ${ }^{[5]}$, so $0.1 \%$ of the dosage in the experiment is adopted. And by calculation, the dosage of air entraining agent is $3 \mathrm{~g}$.

\section{experiment process}

In this experiment, a total of 54 test blocks were made. In the first number 1 18 blocks, ceramisite dosage is $700 \mathrm{~g}$, and the fiber with the length of $3 \mathrm{~mm}, 6 \mathrm{~mm}, 9 \mathrm{~mm}$ and the weight of $40 \mathrm{~g}, 70 \mathrm{~g}, 100 \mathrm{~g}$ is respectively divided into 3 groups, and in each group there are 6 blocks ; The number 19 36 blocks with 1000g ceramic, and the number 37 54 blocks with 1300g ceramic particles, the content of the fiber is the same as that of the first group.

\subsection{Test block pressurization}
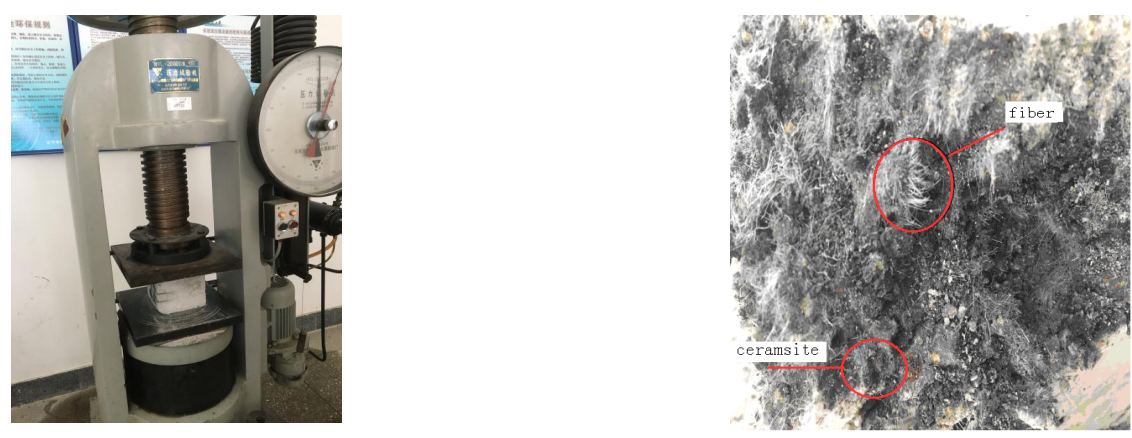

Fig.1 compression-testing machine

Fig.2 block damage chart 
The test block is pressurized by NYL 2000D type pressure testing machine (shown in figure 1)and should pay attention that the contact side of the block must be the smooth surface. As the pressure goes on, the crack will appear and slowly grow until it is destroyed (shown in figure 2).

\section{Analysis of experimental results}

When the ceramsite content is $700 \mathrm{~g}$, fibre size increased from $3 \mathrm{~mm}$ to $6 \mathrm{~mm}$, with the increase of the amount of fiber the compressive strength of specimens increases; The fiber size increased from $6 \mathrm{~mm}$ to $9 \mathrm{~mm}$, the compressive strength decreased; Experiments show that, the maximum test block strength is when the fiber length is $6 \mathrm{~mm}$. The result is shown as Fig 3.

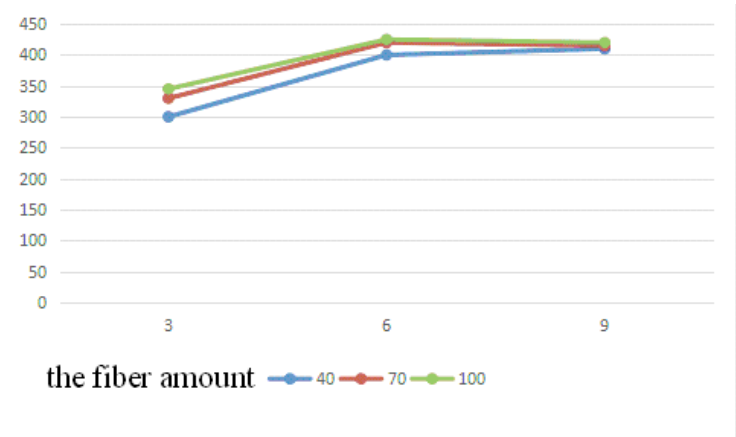

Fig.3 Ceramic concrete strength when ceramsite content is $700 \mathrm{~g}$ ( Mpa )

When ceramsite dosage is $1000 \mathrm{~g}$, as shown in Figure 4, when the fiber specification increases from $3 \mathrm{~mm}$ to $6 \mathrm{~mm}$, the compressive strength of ceramsite concrete blocks generally increases, and the strength decreases with $6 \mathrm{~mm}$ increasing to $9 \mathrm{~mm}$.

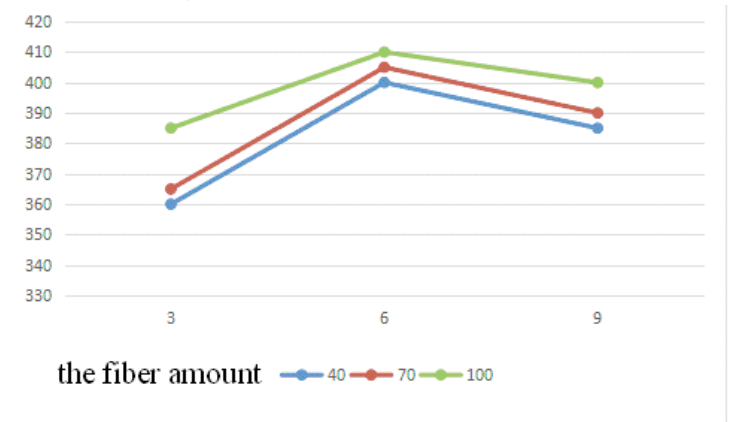

Fig.4 Ceramic concrete strength when ceramsite content is $1000 \mathrm{~g}$ ( Mpa )

When ceramsite dosage is $1300 \mathrm{~g}$, as shown in Figure 5, with the change of fiber specification from $3 \mathrm{~mm}$ to $9 \mathrm{~mm}$, the compressive strength of ceramsite concrete block decreases. In general, when the fiber dosage is $70 \mathrm{~g}$, the strength is the largest, $40 \mathrm{~g}$ time is the second and $100 \mathrm{~g}$ is the smallest.

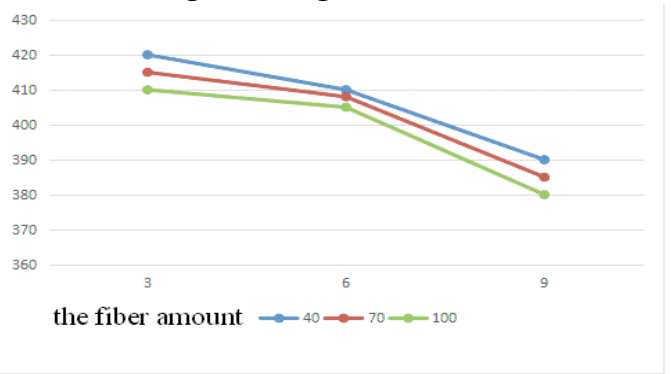

Fig.5 Ceramic concrete strength when ceramsite content is $1300 \mathrm{~g}$ ( Mpa ) 
In the course of the experiment, the time of the crack development is shown as table 2.

Table 2 crack width and cracking time

\begin{tabular}{ccc}
\hline & Type & cracking time (s) \\
crack width $(\mathrm{mm})$ & & 8 \\
\hline 700 & 3 & 17 \\
\hline 1000 & 4 & 15 \\
\hline
\end{tabular}

It can be seen from the table that when the amount of ceramsite is $1000 \mathrm{~g}$, the cracking time is the latest, and the width of the cracking is the smallest.

By Formula 1 to formula 6, the optimal mix ratio is obtained as follows:

sand: ceramsite: water: cement $=33: 30: 12: 25$

\section{Conclusion}

Through the above analysis, we can draw the following conclusions:

(1) With the increase of the amount of ceramsite, the strength of the initial test block increased obviously. However, when the ceramsite dosage is over $1000 \mathrm{~g}$, the compressive strength decreases with the increase of ceramsite dosage. The experiment shows that the ideal strength can be achieved when the content of the ceramsite in the standard test block is $1000 \mathrm{~g}$.

(2) The increase of fiber dosage can increase the compressive strength of the test block in a certain range. The experiment shows that when the fiber specification is $6 \mathrm{~mm}$ and the fiber dosage is $70 \mathrm{~g}$, the compressive strength of the test block is the best.

(3) By considering the strength and cracking resistance comprehensively, the best proportion is put forward in this paper: fiber specification is $6 \mathrm{~mm}$, and sand: ceramsite: water: cement $=33: 30: 12: 25$.

\section{References}

[1] L.J WANG. WB HOU. S LIU. concrete summary of conservation materials and the development and application of research. Concrete. Vol. 290.No12.p. 4-7(2013)

[2] S WANG. M YANG. H.ZHU. D.WANG F.LIU. Experiment research on crushed ceramsited concrete. Industrial Construction .Vol43No4. p.111-115(2013).

[3] W.B LIU. X Q ZhANG. Study of the Performance of Lightweight High-Strength Ceramsite Concrete. Coalash . Vol6 No6.p.42-44(2016).

[4] F ZHUANG. F Y ZHANG .J Y DU. Study of influence of flyash on the properties of mortar. Journal of Shi he zi University (Natural Science).Vol30No(1). p.87-91(2012).

[5] X WANG. Shale Ceramsite Concrete Mix Design and Performance Experimental Study. Sichuan Building Materials. Vol38 .No5. p.16-17(2012) 